\title{
EPSTEIN-BARR VIRUS-ASSOCIATED GASTRIC CARCINOMA IN BRAZIL: COMPARISON BETWEEN IN SITU HYBRIDIZATION AND POLYMERASE CHAIN REACTION DETECTION
}

\section{Marcos Antonio Pereira de Lima ${ }^{1 *}$, Márcia Valéria Pitombeira Ferreira ${ }^{1}$, Marcos Aurélio Pessoa Barros ${ }^{2}$, Maria Inês de Moura Campos Pardini ${ }^{3}$, Adriana Camargo Ferrasi ${ }^{3}$, Silvia Helena Barem Rabenhorst ${ }^{1}$}

${ }^{1}$ Setor de Microbiologia, Departamento de Patologia e Medicina Legal, Universidade Federal do Ceará, Fortaleza, CE, Brasil;

${ }^{2}$ Santa Casa de Misericórdia, Fortaleza, CE, Brasil; ${ }^{3}$ Faculdade de Medicina, Universidade Estadual Paulista, Botucatu, SP, Brasil.

Submitted: February 05, 2011; Returned to authors for corrections: August 22, 2011; Approved: August 30, 2011.

\begin{abstract}
Epstein-Barr virus (EBV) has been associated with $10 \%$ of gastric carcinomas. The aim of this study was to determine the frequency of EBV in gastric carcinomas in Brazil assessed by in situ hybridization (ISH) and PCR, which would contribute to the characterization of the clinical and pathological aspects of EBVassociated gastric carcinomas. One hundred and ninety-two gastric carcinoma cases were collected at hospitals in two Brazilian states. Seventy-three out of 151 cases were PCR(+), while 11/160 cases were ISH(+). Nine out of eleven ISH(+) cases displayed a diffuse staining pattern and 2 out of 11 a focal pattern. Both techniques showed that the $\operatorname{EBV}(+)$ cases were characterized by their association with males, older patients, lower gastric region, intestinal type, advanced stage and poorly to moderately differentiated tumors. The concordance between the two techniques was 55.8\% (Cohen's kappa index $=0.034$ ). Four cases were ISH(+)/PCR(-), while 49 cases were PCR(+)/ISH(-). Only two cases showed stained lymphocytes by ISH and one of them was PCR(-). The observed discrepancy between the two techniques could not be explained just by the elevated accuracy of PCR. ISH(+)/PCR(-) carcinomas may be encountered if EBV is not present in the whole tumor tissue or if there are polymorphisms in the sequences of the viral genome amplified. On the other hand, the high frequency of $\mathrm{PCR}(+)$ results associated with the absence of ISH staining in lymphocytes and/or tumors cells suggests that the virus may be present in tumor cells or other cell types without expressing EBER1, the target of the ISH technique.
\end{abstract}

Key words: Epstein-Barr virus, gastric carcinoma, PCR, ISH.

\section{INTRODUCTION}

The Epstein-Barr virus (EBV) is a Herpesvirus that infects, in a persistent way, more than $90 \%$ of the adult population worldwide, resulting in an asymptomatic outcome in the majority of individuals. However, EBV has been associated with several lymphoid disorders such as infectious mononucleosis, Burkitt's lymphoma, Hodgkin's disease, and

\footnotetext{
*Corresponding Author. Mailing address: Universidade Federal do Ceará, 284 Rua Divino Salvador, Barbalha, Ceará, Brasil, Postal code: 63180-000.; Tel.: +55
} 8833125000 Fax: +55 883312 5002.; E-mail: marcosantonio@ufc.br 
post-transplant lymphoproliferative disease (PTLD), as well as some solid tumors such as nasopharyngeal and gastric carcinomas (42). The association of the EBV with gastric carcinomas was observed at the beginning of the 1990s. The first report was in a case of lymphoepithelial-like gastric carcinoma (7), subsequently, it was identified in common gastric carcinomas (47). Afterwards, many works demonstrated that EBV displays an important role in gastric carcinogenesis, most of them reporting the presence of the virus in almost all tumor cells and the monoclonality of the viral genome $(13,20$, 40).

During the past two decades, several studies in many countries were carried out. Although the polymerase chain reaction $(\mathrm{PCR})$ had been used in the first detection of EBV in gastric carcinoma (7), the majority of studies have used RNA in situ hybridization (ISH) due to the possibility of viral genome amplification from infected lymphocytes infiltrating the tumor, resulting in a false-positive. Still, there are few studies using and comparing both techniques for EBV detection $(13,20,47,57)$.

It has been demonstrated, using RNA in situ hybridization, that EBV can be found in approximately $10 \%$ of gastric carcinomas. However, there are some regional differences in the frequency of EBV-positive gastric carcinoma. Countries with higher values include Japan (19.3\%), Germany (18\%) and United States (12-16\%) (18, 22, 40, 47). Two studies conducted in Brazil demonstrated intermediate values, $8 \%$ and $11.3 \%(27,33)$.

In spite of the several papers regarding EBV frequency in gastric carcinomas, the association of EBV with some clinicopathological aspects is still controversial. Only a few consensuses involving EBV-associated cases have been established including average age of about 59 years old and predominance in males and in poorly to moderately differentiated tumors. Moreover, as mentioned, few studies have correlated results between ISH and PCR techniques. Therefore, the aim of the present study was to determine the occurrence of EBV in gastric carcinomas by RNA in situ hybridization and PCR, comparing the results of the techniques and correlating them with clinico-pathological findings.

\section{MATERIALS AND METHODS}

\section{Clinical Specimens}

One hundred ninety-two cases of surgically resected gastric carcinomas were obtained from Ceará and São Paulo States, Brazil, including two hospitals in Ceará State, namely Hospital Universitário Walter Cantídeo, Universidade Federal do Ceará and Santa Casa de Misericórdia de Fortaleza, and two hospitals in São Paulo State, namely Hospital das Clínicas de Botucatu, Faculdade de Medicina, UNESP, Botucatu and Hospital Amaral Carvalho, Jaú. The present study was previously approved by the Ethics Committee of the Universidade Federal do Ceará under protocol 199/2004, and informed consent was obtained from all participants before gastrectomy, abiding by the Resolution 196/1996 of the National Council of Health - Ministry of Health/Brazil. Clinico-pathological data were collected from the subjects using an administered questionnaire and/or from medical reports. Some clinico-pathological data could not be obtained from the São Paulo samples. Fresh clinical specimens, obtained during the gastrectomies, were immediately sent to the associated laboratories, under refrigeration, and stored in a freezer at $-80^{\circ} \mathrm{C}$. The percentage of tumor cells was determined and only specimens containing at least $70 \%$ tumor cells were submitted to DNA extraction. Therefore, 151 cases were used for PCR analyses. Out of 192 cases, 160 representative specimens of formalin-fixed tumor embedded in paraffin blocks were obtained from the pathology archives of the referred hospitals for ISH application. The specimens were sectioned ( $5 \mu \mathrm{m}$ thickness) and placed on silane-treated glass slides. Moreover, each sample was reviewed by a pathologist of the team to confirm the diagnosis of gastric carcinoma, tumor differentiation and histological type based on Lauren's 
classification. The tumor stages were defined based on the TNM classification present in the medical reports, according to the American Joint Committee on Cancer (4). Both techniques were performed in 120 out of 192 cases.

\section{RNA In Situ Hybridization}

The presence of EBV was assessed utilizing a 30-bp biotinylated probe complementary to viral RNA EBER1 (47). The ISH technique was carried out according to the following steps: deparaffinization; rehydration; endogenous peroxidase blockade with $3 \% \mathrm{H}_{2} \mathrm{O}_{2}$; enzymatic digestion with proteinase $\mathrm{K}$ $(0.02 \mu \mathrm{g} / \mu \mathrm{L})$ for $13 \mathrm{~min}$; incubation with pre-hybridization solution (Denhardt's solution [3.5X], SSC [4.5X], EDTA [0.0075 M], SDS [0.35\%], $\mathrm{NaH}_{2} \mathrm{PO}_{4}[0.75 \mathrm{M}]$, dextran sulfate [10\%]) for $60 \mathrm{~min}$ at $37^{\circ} \mathrm{C}$; overnight incubation at $37^{\circ} \mathrm{C}$ with hybridization solution containing $0.3 \mathrm{ng} / \mu \mathrm{L}$ of the probe; slide washes with $2 \mathrm{X}$ SSC buffer; and signal amplification using anti-biotin antibody (clone BK-1/39, mouse, dilution 1:20; DakoCytomation $^{\circledR}$; Denmark) and biotinylated antiimmunoglobulin antibody (polyclonal, rabbit, dilution 1:100; DakoCytomation $^{\circledR}$; Denmark). The detection was performed using the streptavidin-biotin-peroxidase method (DakoCytomation $^{\circledR}$; CA, USA) and 3,3'-diaminobenzidine (DakoCytomation $^{\circledR}$; CA, USA) as chromogen. In each reaction, an EBV-positive nasopharyngeal carcinoma case was used as positive control while a negative control was obtained by omitting the probe. Nuclei with a brown or black staining were considered positive. To insure that we did not lose any EBVpositive case, with staining in tumor cells and/or lymphocytes, which could have a small amount of EBER1 due to RNA degradation during the histological procedures, thirty random cases were also performed with the GenPoint ${ }^{\circledR}$ detection system (DakoCytomation $^{\circledR}$, Code K0620; CA, USA), following the manufacturer's instructions.

\section{DNA Extraction}

The DNA extraction method was adapted from Foster and
Twell (12), which utilizes the detergent cetyl trimethyl ammonium bromide (CTAB). Briefly, fragments of about $0.5 \mathrm{~g}$ were macerated in tubes containing $6 \mathrm{~mL}$ of extraction buffer (2\% CTAB; $1.4 \mathrm{M} \mathrm{NaCl} ; 20$ mM EDTA; 100 mM Tris-HCl, $\mathrm{pH} 8.0 ; 0.2 \%$ 2-mercaptoethanol), and the contents mixed overnight at room temperature. DNA purification was performed with chloroform-isoamyl alcohol (24:1), with precipitation using $100 \%$ isopropanol; the DNA-CTAB complex was dissociated with the addition of $1 \mathrm{M} \mathrm{NaCl}$. DNA was then precipitated with $100 \%$ ethanol, washed with $70 \%$ ethanol, dried at $37^{\circ} \mathrm{C}$ and dissolved in RNAse- and DNAsefree water. The quality of the DNA extracted was analyzed by electrophoresis in $1 \%$ agarose gels, which were stained with ethidium bromide and observed with a UV transilluminator, and the quantity was measured with a spectrophotometer.

\section{Polymerase Chain Reaction (PCR)}

The EBV genome was detected by amplification of a fragment from the EBNA1 gene utilizing the following primers: sense 5'- GTC ATC ATC ATC CGG GTC -3' and antisense 5'- TTC GGG TTG GAA CCT CCT TG -3' (53). The expected size of the reaction products was $269 \mathrm{bp}$. The reaction mix was composed of $1 \mathrm{X}$ PCR buffer $(20 \mathrm{mM}$ Tris$\mathrm{HCl}$ [pH 8.4], $50 \mathrm{mM} \mathrm{KCl}), 1.25 \mathrm{U}$ Platinum Taq DNA polymerase (Invitrogen ${ }^{\circledR}$; CA, USA), $0.4 \mathrm{mM}$ dNTPs, $1.5 \mathrm{mM}$ $\mathrm{MgCl}_{2}, 0.4 \mu \mathrm{M}$ of each primer; and $100 \mathrm{ng}$ of DNA sample. The amplification cycles were started with an initial denaturation at $94^{\circ} \mathrm{C}$ for $3 \mathrm{~min}$, followed by 35 cycles of denaturation at $94^{\circ} \mathrm{C}$ for $30 \mathrm{~s}$, annealing at $55^{\circ} \mathrm{C}$ for $60 \mathrm{~s}$ and elongation at $72^{\circ} \mathrm{C}$ for $2 \mathrm{~min}$, followed by a final extension at $72^{\circ} \mathrm{C}$ for $7 \mathrm{~min}$. The amplification products were visualized in a 2\% agarose gel stained with ethidium bromide. DNA extracted from Daudi cells was used as a positive control of the reactions, and reaction mix without DNA was used as a negative control. For confirmation of the specificity of reaction, amplification products from the EBNA1 gene were cloned with TOPO TA Cloning Kit (Invitrogen ${ }^{\circledR}$; CA, USA) 
and sequenced using the ABI PRISM ${ }^{\circledR}$ BigDye Terminator v3.0 Cycle Sequencing Kit (Applied Biosystems ${ }^{\circledR}$; CA, USA) and ABI Prism 3100 DNA Sequencer (Applied Biosystems ${ }^{\circledR}$; CA, USA).

\section{Statistical Analysis}

The analyses were carried out using the statistical programs EPINFO $^{\circledR} 6.04 \mathrm{~d}$ and SPSS ${ }^{\circledR}$ 17.0. The data were evaluated by the chi-square test or Fisher's exact test (2-sided). The results were considered statistically significant when p-values were less than 0.05. For the agreement analysis of the techniques, Cohen's kappa index was used and interpreted according to the classification of Landis and Koch (29). Considering the ISH as the gold standard method for EBV detection in tumor tissues, the sensitivity and specificity values were also calculated for PCR.

\section{RESULTS}

The comparison of the clinico-pathological data and EBV detection by ISH and PCR is shown in the Table 1. No statistically significant differences were found between the EBV-associated gastric carcinomas from São Paulo and Ceará States with regard to epidemiological and pathological parameters, and therefore, they were analyzed as one group. Out of 192 cases, the PCR was performed in 151 and ISH in 160, while both techniques were performed in 120 cases. The percentage of positive cases by PCR was higher than by ISH. Seventy-three out of 151 (48.3\%) cases submitted to the PCR technique were EBV-positive (Figure 1), while 11 out of $160(6.9 \%)$ were ISH-positive, showing a strong nuclear staining (Figure 2). The majority (9 out of 11) of the ISHpositive cases exhibited a diffuse staining pattern. In one case with diffuse and one with focal staining pattern, EBV was also observed in lymphocytes. EBV was not observed in surrounding noncancerous or preneoplastic cells. All thirty cases submitted to in situ hybridization utilizing the GenPoint Detection System ${ }^{\circledR}$ demonstrated the same results as with the standard technique: twenty-eight EBV-negative and two EBV-positive cases.

Table 1. Correlation of the clinico-pathological findings with PCR and in situ hybridization data.

\begin{tabular}{|c|c|c|c|c|c|c|c|c|}
\hline & \multicolumn{4}{|c|}{ In situ Hybridization } & \multicolumn{4}{|l|}{ PCR } \\
\hline & & EBV(+) & EBV(-) & $p$-value & & EBV(+) & EBV(-) & $p$-value \\
\hline & $\mathbf{N}$ & $\mathbf{N}(\%)$ & $\mathbf{N}(\%)$ & & $\mathbf{N}$ & $\mathbf{N}(\%)$ & $\mathbf{N}(\%)$ & \\
\hline Total & 160 & $11(6.9)$ & $149(93.1)$ & & 151 & $73(48.3)$ & $78(51.7)$ & \\
\hline Sex & 118 & & & 0.162 & 109 & & & 0.236 \\
\hline Male & & $9(90)$ & $70(64.8)$ & & & $39(65)$ & $37(75.5)$ & \\
\hline Female & & $1(10)$ & $38(35.2)$ & & & $21(35)$ & $12(24.5)$ & \\
\hline Age distribution* & 117 & & & 0.795 & 108 & & & 0.256 \\
\hline $15-44$ & & $1(10)$ & $10(9.3)$ & & & 7 (11.7) & $3(6.3)$ & \\
\hline $45-54$ & & $2(20)$ & $21(19.6)$ & & & $7(11.7)$ & $12(25)$ & \\
\hline $55-64$ & & $1(10)$ & $25(23.4)$ & & & $18(30)$ & $11(22.9)$ & \\
\hline$\geq 65$ & & $6(60)$ & $51(47.7)$ & & & $28(46.6)$ & $22(45.8)$ & \\
\hline Anatomic localization & 157 & & & 0.432 & 126 & & & 0.893 \\
\hline Upper & & $3(27.3)$ & $23(15.8)$ & & & $10(17.5)$ & $11(15.9)$ & \\
\hline Intermediate & & $3(27.3)$ & $29(19.9)$ & & & $9(15.8)$ & $13(18.8)$ & \\
\hline Lower & & $5(45.4)$ & $94(64.3)$ & & & $38(66.7)$ & $45(65.2)$ & \\
\hline Lauren's classification & 160 & & & 0.098 & 150 & & & 0.745 \\
\hline Intestinal & & $10(90.9)$ & $93(62.4)$ & & & $49(68.0)$ & $55(70.5)$ & \\
\hline Diffuse & & $1(9.1)$ & $56(37.5)$ & & & $23(31.9)$ & $23(29.4)$ & \\
\hline Tumor stage & 160 & & & 0.533 & 150 & & & 0.287 \\
\hline In situ & & & & & & $1(1.3)$ & $0(0)$ & \\
\hline IA & & $0(0)$ & $4(2.7)$ & & & $3(4.1)$ & $3(3.9)$ & \\
\hline IB & & $1(9.1)$ & $14(9.4)$ & & & $3(4.1)$ & $10(12.9)$ & \\
\hline II & & $1(9.1)$ & $32(21.5)$ & & & $11(15.1)$ & $18(23.4)$ & \\
\hline IIIA & & $2(18.2)$ & $41(27.5)$ & & & $18(24.7)$ & $17(22.1)$ & \\
\hline IIIB & & $4(36.3)$ & $23(15.4)$ & & & $16(21.9)$ & $12(15.6)$ & \\
\hline IV & & $3(27.3)$ & $35(23.5)$ & & & $21(28.8)$ & $17(22.1)$ & \\
\hline Tumor differentiation & 156 & & & 0.497 & 118 & & & 0.663 \\
\hline Undifferentiated & & $0(0)$ & $1(0.7)$ & & & $1(1.9)$ & $0(0)$ & \\
\hline Poorly & & $3(30)$ & $58(39.7)$ & & & $19(35.2)$ & $25(39.1)$ & \\
\hline Moderately & & $7(70)$ & $70(47.9)$ & & & $27(50)$ & $29(45.3)$ & \\
\hline Well differentiated & & $0(0)$ & $17(11.6)$ & & & $7(12.9)$ & $10(15.6)$ & \\
\hline
\end{tabular}




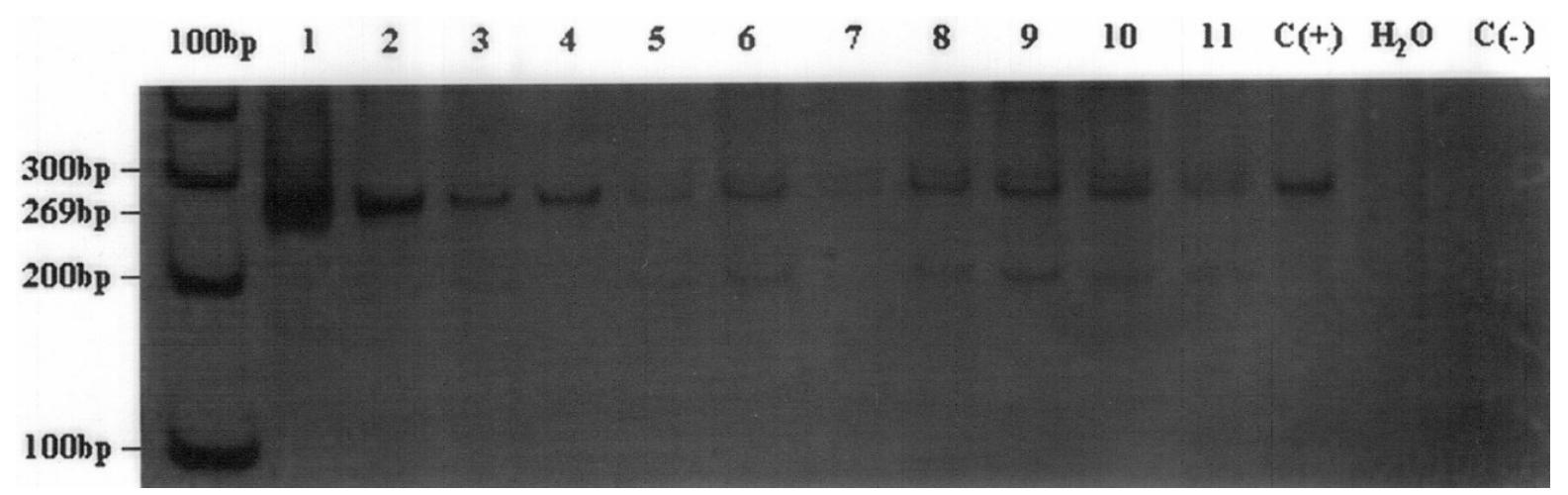

Figure 1. Agarose gel electrophoresis of products from EBNA1 gene amplification (269 bp). 100bp = ladder; Lanes 1-11 = EBVpositive samples; $\mathrm{C}(+)=$ positive control; $\mathrm{H}_{2} \mathrm{O}=$ water; $\mathrm{C}(-)=$ negative control.

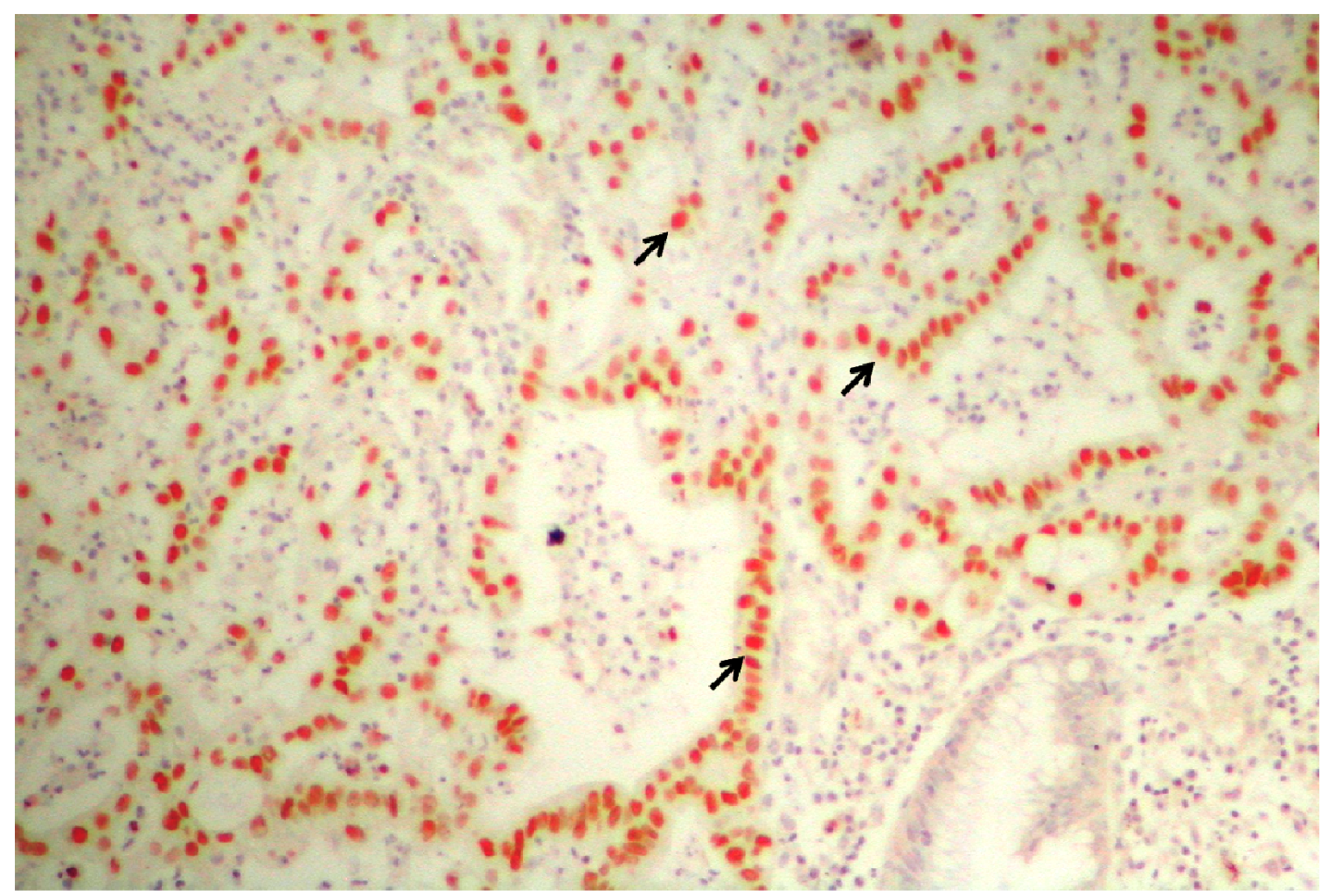

Figure 2. Detection of EBV by in situ hybridization. Strong nuclear staining was observed in gastric carcinoma cells (arrows).

Although statistically significant differences were not found between the $\operatorname{EBV}(+)$ and $\operatorname{EBV}(-)$ tumors, by either technique, a predominance of EBV-positive cases was observed in males and in older individuals. The intestinal tumors were the most frequent subtype and the lower gastric region was the most frequent gastric localization associated with EBV. Nevertheless, the majority of the cases were in advanced stages, especially in the IIIB and IV, and in the moderately differentiated tumors. Despite these characteristics being found by both techniques, they were more evident by 
ISH, which is seen by the trend $(p=0.09)$ for the intestinal-type tumors in the EBV-positive cases. However, the ISH-positive cases showed a slight increase in tumors localized in the upper and intermediate regions in comparison with ISH-negative cases.

The correlation between PCR and ISH is shown in the Table 2. Among the 120 investigated cases, there was agreement in $67(55.8 \%)$, including $(+/+)$ and (-/-) cases. Disagreement was observed in $53(44.2 \%)$ cases. EBV was detected by both techniques only in 5 out of 120 cases $(4.1 \%)$, while both methods showed negative results in 62 cases $(51.6 \%)$. Nevertheless, 4 (3.3\%) ISH-positive cases were PCRnegative, while 49 (40.8\%) PCR-positive cases were ISHnegative. Cohen's kappa index was 0.034, whereas the PCR method demonstrated a sensitivity value of $55.5 \%$ and specificity value of $55.8 \%$.

Table 2. Correlation between the results of the PCR and in situ hybridization techniques.

\begin{tabular}{cccc}
\hline & \multicolumn{2}{c}{$\boldsymbol{P C R}$} & \\
\cline { 2 - 3 } In situ Hybridization & EBV (+) & EBV (-) & Total \\
\hline EBV (+) & 5 & 4 & 9 \\
EBV (-) & 49 & 62 & 111 \\
\hline Total & 54 & 66 & 120 \\
\hline Cohen's kappa index: 0.034 (SE: 0.052$)$; Sensibility: $55.5 \%$ Specificity: $55.8 \%$
\end{tabular}

\section{DISCUSSION}

Gastric cancer is the fourth most frequent neoplasm in the world and the second leading cause of death from cancer (6, 41). According to the Brazilian National Cancer Institute (6), gastric cancer is the fourth most common cancer among men and the sixth among women. Regarding the EBV association, in spite of consensus about some clinico-histopathological aspects of EBV-associated gastric carcinomas, there is still controversy in the literature on some points, given the complexity of this type of cancer. In this context, the present study contributes new data, considering the clinicopathological features versus the EBV infection in cases from two Brazilian states that have a high incidence of gastric cancer. Nevertheless, few studies have used PCR for EBV detection, and most of them have used this technique as screening prior to the application of ISH due to the possibility of viral genome amplification from infected lymphocytes in the tumor stroma, as discussed by Trimeche et al. (55). In the present work, both techniques were independently performed and their results were compared.

The frequency of EBV-positive gastric carcinoma varies widely around the world, ranging from $0 \%$ to $23.6 \%$ (Table 3). In this study, the overall frequency of EBV by ISH $(6.9 \%)$ is in agreement with the two other Brazilian studies, even considering that the two studied regions have different habits and socioeconomic conditions (27, 33). These frequencies were also similar to those found in Mexico $(8.1 \%)$, France $(8.5 \%)$, China $(6.4 \%$ - 7\%), Korea (5.6\% - 7.3\%), Russia (8.7\%), Japan (5.2\% - 6.7\%) and USA (5.1\%) $(9,14$, $19,21,24,26,30,34,35,38,46,52,54,56,57)$. The highest EBV frequencies were found in the USA (16\%), Germany (18\%; 19.6\%), Japan (19.3\%), Korea (19.6\%), and Chile $(23.6 \%)(10,15,22,25,40,47)$ and the lowest frequencies in Peru (3.9\%), England (0\%), United Kingdom (1.8\%), New Guinea $(1.3 \%)$, Iran $(3.2 \%)$, Tunisia $(4.1 \%)$ and Italy $(4.6 \%)$ $(1,31,36,43,49,55,59)$. The presence of both high and low frequencies in developed and developing countries indicates that economic conditions are not a relevant aspect for EBVassociated gastric carcinomas. On the other hand, the EBV detection by PCR $(48.3 \%)$ demonstrated a frequency similar to that obtained by Nakamura et al. (37) (47\%), but different from the results obtained by Leoncini et al. (31), Oda et al. (38) and Trimeche et al. (55), 6.1\%, $21.6 \%$ and 36\%, respectively. In general, all PCR frequencies were higher than ISH frequencies. In the present study, sequencing of the amplification products confirmed the specificity of PCR. 
Table 3. Summary of studies, clustered by world regions, which evaluate the association of the EBV with gastric carcinomas.

\begin{tabular}{|c|c|c|c|c|c|c|c|}
\hline Country & Techniques & Freq. & $\%$ & Tumor type & Cell type stained & Reference & Year \\
\hline \multirow[t]{6}{*}{ USA } & PCR & $1 / 1$ & 100 & Lymphoepithelial type carcinoma & Tumor cells & 7 & 1990 \\
\hline & PCR & NR & - & Carcinoma & Tumor cells & 47 & 1992 \\
\hline & ISH-DNA* & $22 / 138$ & 16 & & Dysplastic epithelium & & \\
\hline & ISH-EBER1 & $22 / 138$ & 16 & & & & \\
\hline & ISH-EBER1 & $11 / 95$ & 12 & Carcinoma & $\begin{array}{l}\text { Tumor cells } \\
\text { Dysplastic epithelium }\end{array}$ & 18 & 1996 \\
\hline & ISH-EBER & $12 / 235$ & 5.1 & Carcinoma & Tumor cells & 56 & 2009 \\
\hline Mexico & ISH-EBER1 & $11 / 135$ & 8.1 & Carcinoma & Tumor cells & 21 & 1999 \\
\hline \multirow[t]{2}{*}{ Brazil } & ISH-EBER1 & $24 / 300$ & 8 & Carcinoma & Tumor cells & 27 & 2001 \\
\hline & ISH-EBER1 & $6 / 53$ & 11.3 & Carcinoma & Tumor cells & 33 & 2004 \\
\hline Colombia & ISH-EBER1 & $23 / 178$ & 13 & Carcinoma & Tumor cells & 8 & 2003 \\
\hline Peru & ISH-EBER1 & $10 / 254$ & 3.9 & Carcinoma & Tumor cells & 59 & 2005 \\
\hline Chile & ISH-EBER1 & $22 / 93$ & 23.6 & Carcinoma (only cardia tumors) & Tumor cells & 10 & 2005 \\
\hline UK & ISH-EBER1 & $3 / 168$ & 1.8 & Carcinoma & Tumor cells & 43 & 1993 \\
\hline England & ISH-EBER1 & $0 / 17$ & 0 & Carcinoma & - & 49 & 1994 \\
\hline France & ISH-EBER1 & $5 / 59$ & 8.5 & Carcinoma & $\begin{array}{l}\text { Tumor cells } \\
\text { Surrouding lymphocytes }\end{array}$ & 46 & 1996 \\
\hline \multirow[t]{2}{*}{ Germany } & ISH-EBER1 & $7 / 39$ & 18 & Carcinoma & Tumor cells & 40 & 1994 \\
\hline & ISH-EBER & $18 / 92$ & 19.5 & Carcinoma & Tumor cells & 15 & 2011 \\
\hline \multirow[t]{2}{*}{ Italy } & PCR & $4 / 65$ & 6.1 & Carcinoma & Tumor cells & 31 & 1993 \\
\hline & ISH-EBER1 & $3 / 65$ & 4.6 & & & & \\
\hline \multirow[t]{10}{*}{ Japan } & ISH-EBER1 & $120 / 1795$ & 6.7 & Carcinoma & $\begin{array}{l}\text { Tumor cells } \\
\text { Surrouding lymphocytes }\end{array}$ & 54 & 1993 \\
\hline & PCR & NR & - & Carcinoma & Tumor cells & 13 & 1994 \\
\hline & ISH-EBER1 & $8 / 72$ & 11 & & $\begin{array}{l}\text { Surrouding lymphocytes } \\
\text { Non-neoplastic epithelium }\end{array}$ & & \\
\hline & PCR & $46 / 99$ & 47 & Carcinoma & Tumor cells & 37 & 1994 \\
\hline & ISH-EBER1 & $4 / 42$ & 9.5 & & & & \\
\hline & ISH-EBER1 & $33 / 513$ & 6.4 & Carcinoma & $\begin{array}{l}\text { Tumor cells } \\
\text { Surrouding lymphocytes }\end{array}$ & 52 & 1999 \\
\hline & ISH-EBER1 & $23 / 119$ & 19.3 & Carcinoma & Tumor cells & 22 & 2001 \\
\hline & PCR & $21 / 97$ & 21.6 & Carcinoma & Tumor cells & 38 & 2003 \\
\hline & ISH-EBER1 & $5 / 97$ & 5.2 & & Surrouding lymphocytes & & \\
\hline & ISH-EBER1 & $28 / 417$ & 6.7 & Carcinoma & Tumor cells & 24 & 2003 \\
\hline \multirow[t]{7}{*}{ China } & ISH-EBER1 & $7 / 74$ & 9.5 & Carcinoma & Tumor cells & 60 & 1994 \\
\hline & & & & & $\begin{array}{l}\text { Dysplastic epithelium } \\
\text { Surrouding lymphocytes }\end{array}$ & & \\
\hline & ISH-EBER1 & $13 / 185$ & 7 & Carcinoma & Tumor cells & 57 & 2004 \\
\hline & ISH-EBER1 & $11 / 172$ & 6.4 & Carcinoma & Tumor cells & 34 & 2005 \\
\hline & $\begin{array}{l}\text { PCR-Southern } \\
\text { blot }\end{array}$ & NR & - & Carcinoma & Tumor cells & 35 & 2006 \\
\hline & ISH-EBER1 & $13 / 185$ & 7.03 & & & & \\
\hline & ISH-EBER1 & $45 / 676$ & 6.7 & Carcinoma & Tumor cells & 19 & 2010 \\
\hline \multirow[t]{2}{*}{ Thailand } & PCR & NR & - & Carcinoma & Tumor cells & 20 & 1995 \\
\hline & ISH-EBER1 & $6 / 55$ & 11 & & Dysplastic epithelium & & \\
\hline \multirow[t]{5}{*}{ Korea } & ISH-EBER1 & $12 / 89$ & 13.5 & Carcinoma & Tumor cells & 48 & 1996 \\
\hline & ISH-EBER1 & $17 / 306$ & 5.6 & Carcinoma & $\begin{array}{l}\text { Tumor cells } \\
\text { Surrouding lymphocytes }\end{array}$ & 9 & 2001 \\
\hline & ISH-EBER1 & $63 / 1127$ & 5.6 & Carcinoma & Tumor cells & 30 & 2004 \\
\hline & ISH-EBER & $23 / 117$ & 19.6 & Carcinoma & Tumor cells & 25 & 2010 \\
\hline & ISH-EBER & $18 / 247$ & 7.3 & Carcinoma & Tumor cells & 26 & 2010 \\
\hline Russia & ISH-EBER1 & $18 / 206$ & 8.7 & Carcinoma & Tumor cells & 14 & 1997 \\
\hline Malaysia & ISH-EBER1 & $5 / 50$ & 10 & Carcinoma & Tumor cells & 23 & 2003 \\
\hline New Guinea & ISH-EBER1 & $2 / 150$ & 1.3 & Carcinoma & Tumor cells & 36 & 2004 \\
\hline Kazakhstan & ISH-EBER1 & $14 / 139$ & 10.1 & Carcinoma & Tumor cells & 2 & 2005 \\
\hline \multirow[t]{2}{*}{ Tunisia } & ISH-EBER & $35 / 96$ & 36.4 & Carcinoma & Tumor cells & 55 & 2009 \\
\hline & & $4 / 96$ & 4.1 & & $\begin{array}{l}\text { Non-neoplastic } \\
\text { epithelial cells }\end{array}$ & & \\
\hline Iran & ISH-EBER1 & $9 / 273$ & 3.2 & Carcinoma & Tumor cells & 1 & 2007 \\
\hline
\end{tabular}

* ISH targeted to the viral DNA

NR, not reported 
The predominance of EBV-positive cases in males and in advanced ages was observed by both techniques (PCR and ISH) and reproduced the findings obtained by many authors around the world using the ISH technique $(2,8,15,19,22,25$, $26,28,30,33,38,47,52,55,56,61)$. No clinico-pathological data were found related to EBV detection by PCR in the literature.

Unlike the data for PCR detection, the data for the ISHpositive cases showed somewhat more frequent localization in the upper and intermediate gastric regions compared to the ISH-negative cases and displayed a strong trend for the intestinal type. These findings agree with other studies that point to the cardia and corpus as the gastric regions more associated with EBV-ISH-positive cases (13, 14, 19, 25, 28, 39, 54, 55, 59). However, the correlation with Lauren's classification is still controversial. In this scenario, the present finding corroborates the findings of some authors, indicating the intestinal type as being more associated with EBV-positive gastric carcinomas $(20,60,61)$, but others indicate the diffuse type $(2,19,25,28,38)$ or similar frequencies between the two histological types $(8,47,55)$. Nevertheless, Kijima et al. (24) reported that individuals with intestinal-type EBV-ISH-positive carcinomas have a worse prognosis than with the diffuse type, which corroborates the observed predominance of EBV-ISHpositive cases in advanced tumor stages (IIIB and IV). Although no significance was found related to the presence of the EBV in moderately or poorly differentiated tumors, by either technique, it is in agreement with the few papers found in the literature $(14,31,52,56,59)$.

The comparison of the results from the two techniques employed showed no concordance as indicated by Cohen's kappa index $(\kappa=0.034)$, which according to Landis and Koch (29) represents a slight agreement. Furthermore, the sensitivity and specificity values for PCR did not show satisfactory values, i.e., $55.5 \%$ and $55.8 \%$, respectively. In this context, Gulley (17) attributes the elevated frequency of EBV-positive cases detected by PCR to the amplification of viral DNA from surrounding infected lymphocytes, not from tumor cells, explaining the low specificity value. However, among the 160 cases evaluated by ISH, only two displayed infected lymphocytes, with both of them also exhibiting stained tumor cells and one even being PCR-negative. To verify whether the low frequency of ISH-positive lymphocytes was due to the small quantity of circulating infected lymphocytes, complementary tumor specimens (other paraffin blocks) were obtained from four random PCR-positive cases and likewise submitted to ISH, but like the first results with the main specimens, no infected lymphocytes were observed. Another hypothesis refers to a possible reduced EBER1 expression in tumor cells or lymphocytes to undetectable levels due to RNA degradation during histological procedures as suggested by Gulley (17); however, the employment of a more sensitive ISH method by GenPoint ${ }^{\circledR}$ confirmed the ISH negativity in the twenty-eight samples tested. This technique employs tyramide amplification reagents and assures the potential detection of single-copy nucleic acid $(11,32)$.

Regarding this point, our findings raise the following query: How do we account for the high EBV frequency by PCR, in view of the low number of infiltrating infected lymphocytes in the tumor tissue? In this context, Oda et al. (38) evaluated cases with EBV-negative tumor cells by ISH, and found 14 PCR-negative cases with the presence of infected lymphocytes detected by ISH and 10 PCR-positive cases with no evidence of infected lymphocytes. These findings suggest that the PCR results, at least in part, were not related to the presence of infected lymphocytes. Meanwhile, Ryan et al. (45), using quantitative-PCR to estimate EBV load in gastric carcinomas by the analysis of five viral regions and comparing the findings with the standard ISH results, established thresholds to define what is EBV detection in tumor cells, in surrounding lymphocytes or in non-neoplastic epithelium, with the highest viral loads in the cases exhibiting ISH-positive tumor cells. Additionally, the above-mentioned work shows two important findings that can help us resolve some 
uncertainties encountered. First, the verification of polymorphisms in the EBV genome, which impaired the amplification of some viral genes in a few cases, could explain the PCR-negative cases with ISH-positivity in tumor cells and lymphocytes. Second, the presence of cases with low viral loads associated with ISH-negativity for both tumor cells and lymphocytes, attributed by the authors to the presence of EBV in non-neoplastic gastric epithelium, could explain the PCRpositive cases with no evidence of ISH-positivity. This first consideration could also explain the low sensitivity value of PCR in relation to the ISH method.

Nevertheless, some studies have demonstrated, using the ISH method with the EBER1 probe, the presence of EBV in dysplastic tissue, and even in non-tumor tissue surrounding the tumor $(13,18,20,47,55,60)$. However, this is a controversial issue. Curiously, Yanai et al. (58) demonstrated the presence of EBV in dysplastic tissue in two cases of chronic atrophic gastritis with the ISH method targeting the viral genome. Considering these data, it is possible that the non-tumor gastric epithelium may be a reservoir for EBV, as suggested by Takada (51), showing a different behavior at this site. One hypothesis could be a latency pattern different from that usually observed in tumor cells, characterized by the absence of EBER1 expression. This condition corroborates the explanation for DNA amplification and the ISH-negativity in tumor cells and/or surrounding lymphocytes, as well as the results of Yanai et al. (58).

Although EBERs are expressed in four known latency patterns, some authors have already reported the absence of these viral RNAs in some EBV-associated tumors such as hepatocellular carcinomas (50) and breast carcinomas $(5,16)$. Therefore, in order to elucidate this issue, it would be better to use a more sensitive in situ hybridization method, such as the GenPoint system, with the probe targeting a conserved region of EBV DNA, preferentially the BamH1W sequence, because this is a repetitive region that shows approximately 10 copies per EBV genome (44).
Among the four ISH-positive/PCR-negative cases, two demonstrated a focal staining pattern by ISH, initially suggesting that the specimens subjected to PCR had no EBV genome. On the other hand, the two remaining cases exhibited a diffuse staining pattern, suggesting one of the following explanations: (a) experiment failure; (b) DNA degradation; (c) the absence of EBV in some parts of the tumor; or (d) presence of polymorphisms in the sequences of the viral genome amplified. Notably, the experiments were repeated and the initial results were corroborated. DNA preservation was also confirmed by amplification of different genes in other on-going studies in our laboratory. Considering that focal staining by ISH was observed in two cases, it is possible that the virus was not present in the whole tumor; maybe the infection had occurred after tumor transformation or the EBV had trigged the "hit and run mechanism" after tumor establishment, as proposed by Ambinder (3). However, it looks more probable that the PCR negativity in these four cases were due to polymorphisms in the viral genome resulting in false-negatives, as verified by Ryan et al. (45).

\section{CONCLUSIONS}

In summary, there was no concordance between the two techniques, PCR using primers for the EBNA1 gene and ISH for EBER1 detection. Considering that this disagreement was not due to DNA or RNA degradation, we believe that the existence of another latency pattern, characterized by the absence of EBER1 expression, as well as the possibility that EBV in some cases is not present in the whole tumor or that there are polymorphisms in the sequences of the viral genome amplified by the primers used, could explain the observed discrepancy. However, different approaches are needed to confirm this hypothesis and the importance of EBV detection by PCR for elucidating tumor pathology. Moreover, in this study EBV-positive gastric carcinomas were characterized by their association with males, older patients, lower gastric 
region, intestinal type, advanced stage and poorly to moderately differentiated tumors.

\section{REFERENCES}

1. Abdirad, A.; Ghaderi-Sohi, S.; Shuyama, K.; Koriyama, C.; NadimiBarforoosh, H.; Emami, S.; Mosavi-Jarrahi, A.; Nahvijou, A.; Akiba, S. (2007). Epstein-Barr virus associated gastric carcinoma: a report from Iran in the last four decades. Diagnostic Pathology. 2(25), 1-9.

2. Alipov, G.; Nakayama, T.; Nakashima, M.; Wen, C.Y.; Niino, D.; Kondo, H.; Pruglo, Y.; Sekine, I. (2005). Epstein-Barr virus-associated gastric carcinoma in Kazakhstan. World J. Gastroenterol. 11(1), 27-30.

3. Ambinder, R. F. (2000). Gammaherpesviruses and "Hit-and-Run" oncogenesis. Am. J. Pathol. 156(1), 1-3.

4. American Joint Committee on Cancer - AJCC (2002). Cancer Staging Handbook. From the AJCC Cancer Staging Manual. 6.ed. Springer.

5. Bonnet, M.; Guinebretiere, J.M.; Kremmer, E.; Grunewald, V.; Benhamou, E.; Contesso, G.; Joab, I. (1999). Detection of Epstein-Barr virus in invasive breast cancers. J. Natl. Cancer Inst. 91(16), 1376-81.

6. Brazil. Ministry of Health. Secretaria for Health Assistance. National Cancer Institute - INCA (2009). Prevention and Surveillance Coordination Unit. Estimate 2010: Incidence of cancer in Brazil. Rio de Janeiro: NCI.

7. Burke, A.P.; Yen, T.S.; Shekitka, K.M.; Sobin, L.H. (1990). Lymphoepithelial carcinoma of the stomach with Epstein-Barr virus demonstrated by polymerase chain reaction. Mod. Pathol. 3(3), 377-80.

8. Carrascal, E.; Koriyama, C.; Akiba, S.; Tamayo, O.; Itoh, T.; Eizuru, Y.; Garcia, F.; Sera, M.; Carrasquilla, G.; Piazuelo, M.B.; Florez, L.; Bravo, J.C. (2003). Epstein-Barr virus-associated gastric carcinoma in Cali, Colombia. Oncol. Rep. 10(4), 1059-62.

9. Cho, Y.J.; Chang, M.S.; Park, S.H.; Kim, H.S.; Kim, W.H. (2001). In situ hybridization of Epstein-Barr virus in tumor cells and tumor-infiltrating lymphocytes of the gastrointestinal tract. Human Pathology. 32(3), 297301.

10. Corvalán, A.; Akiba, S.; Valenzuela, M.T.; Cumsille, M.A.; Koriyama, C.; Argandoña, J.; Backhouse, C.; Bal, M.; Mena, F.; Palma, M.; Eizuru, Y. (2005). Clinical and molecular features of cardiac gastric cancer associated to Epstein Barr virus. Rev. Med. Chil. 133(7), 753-60.

11. Evans, M.F.; Aliesky, H.A.; Cooper, K. (2003). Optimization of biotinyltyramide-based in situ hybridization for sensitive background-free applications on formalin-fixed, paraffin-embedded tissue specimens. BMC Clin Pathol. 3(1), 2.

12. Foster, G.D.; Twell, D. (1996). Plant Gene Isolation. Principles and Practices. John Wiley \& Sons Ltd., England.

13. Fukayama, M.; Hayashi, Y.; Iwasaki, Y.; Chong, J.; Ooba, T.; Takizawa,
T.; Koike, M.; Mizutani, S.; Miyaki, M.; Hirai, K. (1994). Epstein-Barr virus-associated gastric carcinoma and Epstein-Barr virus infection of the stomach. Lab. Invest. 71(1), 73-81.

14. Galetsky, S.A.; Tsvetnov, V.V.; Land, C.E.; Afanasieva, T.A.; Petrovichev, N.N.; Gurtsevitch, V.E.; Tokunaga, M. (1997). EpsteinBarr-virus associated-gastric cancer in Russia. Int. J. Cancer. 73, 786-9.

15. Geddert, H.; Zur Hausen, A.; Gabbert, H. E.; Sarbia, M. (2011). EBVinfection in cardiac and non-cardiac gastric adenocarcinomas is associated with promoter methylation of $p 16, p 14$ and $A P C$, but not hMLH1. Cell Oncol. Epub ahead of print.

16. Grinstein, S.; Preciado, M.V.; Gattuso, P.; Chabay, P.A.; Warren, W.H.; De Matteo, E.; Gould, V.E. (2002). Demonstration of Epstein-Barr virus in carcinomas of various sites. Cancer Res. 62(17), 4876-8.

17. Gulley, M. L. (2001) Molecular diagnosis of Epstein-Barr virus-related diseases. J. Mol. Diagn., 3(1), 1-10.

18. Gulley, M.L.; Pulitzer, D.R.; Eagan, P.A.; Schneider, B.G. (1996). Epstein-Barr virus infection is an early event in gastric carcinogenesis and is independent of bcl-2 expression and p53 accumulation. Hum. Pathol. 27(1), 20-7.

19. Han, J.; He, D.; Feng, Z. Y.; Ding, Y. G.; Shao, C. K. (2010). Clinicopathologic features and protein expression study of Epstein-Barr virus-associated gastric carcinoma in Guangzhou. Zhonghua Bing Li Xue Za Zhi. 39(12), 798-803.

20. Harn, H.J.; Chang, J.Y.; Wang, M.W.; Ho, L.I.; Lee, H.S.; Chiang, J.H.; Lee, W.H. (1995). Epstein-Barr virus-associated gastric adenocarcinoma in Taiwan. Hum. Pathol. 26(3), 267-71.

21. Herrera-Goepfert, R.; Reyes, E.; Hernandez-Avila, M.; Mohar, A.; Shinkura, R.; Fujiyama, C.; Akiba, S.; Eizuru, Y.; Harada, Y.; Tokunaga, M. (1999). Epstein-Barr-virus associated gastric carcinoma in Mexico: Analysis of 135 consecutive gastrectomies in two hospitals. Mod. Pathol. $12,873-8$

22. Ishii, H.; Gobé, G.; Kawakubo, Y.; Sato, Y.; Ebihara, Y. (2001). Interrelationship between Epstein-Barr virus infection in gastric carcinomas and the expression of apoptosis-associated proteins. Histopathol. 38, 111-9.

23. Karim, N.; Pallesen, G. (2003). Epstein-Barr virus (EBV) and gastric carcinoma in Malaysian patients. Malays. J. Pathol. 25(1), 45-7.

24. Kijima, Y.; Ishigami, S.; Hokita, S.; Koriyama, C.; Akiba, S.; Eizuru, Y.; Aikou, T. (2003). The comparison of prognosis between Epstein-Barr virus (EBV)-positive gastric carcinomas and EBV-negative ones. Cancer Lett. 200(1), 33-40.

25. Kim, B.; Byun, S.; Kim, Y. A.; Kim, J. E.; Lee, B. L.; Kim, W. H.; Chang, M. S. (2010). Cell cycle regulators, APC/ $\beta$-catenin, NF- $\mathrm{KB}$ and Epstein-Barr virus in gastric carcinomas. Pathology. 42(1), 58-65.

26. Kim, R. H.; Chang, M. S.; Kim, H. J.; Song, K. S.; Kim, Y. S.; Choi, B. Y.; Kim, W. H. (2010). Medical history and lifestyle factors contributing 
to Epstein-Barr virus-associated gastric carcinoma and conventional gastric carcinoma in Korea. Anticancer Res. 30(6), 2469-75.

27. Koriyama, C.; Akiba, S.; Iriya, K.; Yamaguti, T.; Hamada, G.S.; Itoh, T.; Eizuru, Y.; Aikou, T.; Watanabe, S.; Tsugane, S.; Tokunaga, M. (2001). Epstein-Barr virus-associated Gastric Carcinoma in Japanese Brazilians and Non-Japanese Brazilians in Sao Paulo. Jpn. J. Cancer Res. 92(9), 911-7.

28. Koriyama, C.; Akiba, S.; Corvalan, A.; Carrascal, E.; Itoh, T.; HerreraGoepfert, R.; Eizuru, Y.; Tokunaga, M. (2004). Histology-specific gender, age and tumor-location distributions of Epstein-Barr virusassociated gastric carcinoma in Japan. Oncol. Rep. 12(3), 543-7.

29. Landis, J. R.; Koch, G. G. (1977). The measurement of observer agreement for categorical data. Biometrics. 33(1), 159-74.

30. Lee, H.S.; Chang, M.S.; Yang, H.; Lee, B.L.; Kim, W.H. (2004). EpsteinBarr virus-positive gastric carcinoma has a distinct protein expression profile in comparison with Epstein-Barr virus-negative carcinoma. Clin. Cancer Res. 10, 1698-1705.

31. Leoncini, L.; Vindigni, C.; Megha, T.; Funtò, I.; Pacenti, L.; Musarò, M.; Renieri, A.; Seri, M.; Anagnostopoulos, J.; Tosi, P. (1993). Epstein-Barr virus and gastric cancer: data and unanswered questions. Int. J. Cancer. 53(6), 898-901.

32. Lizard, G.; Démares-Poulet, M.J.; Roignot, P.; Gambert, P. (2001). In situ hybridization detection of single-copy human papillomavirus on isolated cells, using a catalyzed signal amplification system: GenPoint. Diagn Cytopathol. 24(2), 112-6.

33. Lopes, L.F.; Bacchi, M.M.; Elgui-de-Oliveira, D.; Zanati, S.G.; Alvarenga, M.; Bacchi, C.E. (2004). Epstein-Barr virus infection and gastric carcinoma in São Paulo State, Brazil. Braz. J. Med. Biol. Res. 37(11), 1707-12.

34. Luo, B.; Wang, Y.; Wang, X.; Liang, H.; Yan, L.; Huang, B.; Zhao, P. (2005). Expression of Epstein-Barr virus genes in EBV-associated gastric carcinomas. World. J. Gastroenterol. 11(5), 629-33.

35. Luo, B.; Wang, Y.; Wang, X.F.; Gad, Y.; Huang, B.H.; Zhao, P. (2006). Correlation of Epstein-Barr virus and its encoded proteins with Helicobacter pylori and expression of c-met and c-myc in gastric carcinoma. World J. Gastroenterol. 12(12), 1842-8.

36. Morewaya, J.; Koriyama, C.; Akiba, S.; Shan, D.; Itoh, T.; Eizuru, Y. (2004). Epstein-Barr virus-associated gastric carcinoma in Papua New Guinea. Oncol. Rep. 12(5), 1093-8.

37. Nakamura, S.; Ueki, T.; Yao, T.; Ueyama, T.; Tsuneyoshi, M. (1994). Epstein-Barr virus in gastric carcinoma with lymphoid stroma. Special reference to its detection by the polymerase chain reaction and in situ hybridization in 99 tumors, including a morphologic analysis. Cancer. 73(9), 2239-49.

38. Oda, K.; Koda, K.; Takiguchi, N.; Nunomura, M.; Seike, K.; Miyazaki, M. (2003). Detection of Epstein-Barr virus in gastric carcinoma cells and surrounding lymphocytes. Gastric Cancer. 6(3), 173-8.

39. Osato, T.; Imai, S. (1996). Epstein-Barr virus and gastric carcinoma. Semin. Cancer Biol. 7(4), 175-82.

40. Ott, G.; Kirchner, T.; Müller-Hermelink, H.K. (1994). Monoclonal Epstein-Barr virus genomes but lack of EBV-related protein expression in different types of gastric carcinoma. Histopathology. 25(4), 323-9.

41. Parkin, D.M.; Bray, F.; Ferlay, J.; Pisani, P. (2005). Global Cancer Statistics, 2002. CA Cancer J. Clin. 55, 74-108.

42. Ribeiro-Silva, A.; Zucoloto, S. (2003). The Role of Epstein-Barr virus in human tumorigenesis. Medicina, Ribeirão Preto. 36, 16-23.

43. Rowlands, D.C.; Ito, M.; Mangham, D.C.; Reynolds, G.; Herbst, H.; Hallissey, M.T.; Fielding, J.W.; Newbold, K.M.; Jones, E.L.; Young, L.S. (1993). Epstein-Barr virus and carcinomas: rare association of the virus with gastric adenocarcinomas. Br. J. Cancer. 68(5), 1014-9.

44. Ryan, J.L.; Fan, H.; Glaser, S.L.; Schichman, S.A.; Raab-Traub, N.; Gulley, M.L. (2004). Epstein-Barr virus quantitation by real-time PCR targeting multiple gene segments: a novel approach to screen for the virus in paraffin-embedded tissue and plasma. J Mol Diagn. 6(4), 37885.

45. Ryan, J.L.; Morgan, D.R.; Dominguez, R.L.; Thorne, L.B.; Elmore, S.H.; Mino-Kenudson, M.; Lauwers, G.Y.; Booker, J.K.; Gulley, M.L. (2009). High levels of Epstein-Barr virus DNA in latently infected gastric adenocarcinoma. Lab Invest. 89(1), 80-90.

46. Selves, J.; Bibeau, F.; Brousset, P.; Meggetto, F.; Mazerolles, C.; Voigt, J.J.; Pradere, B.; Chiotasso, P.; Delsol, G. (1996). Epstein-Barr virus latent and replicative gene expression in gastric carcinoma. Histopathology. 28(2), 121-7.

47. Shibata, D.; Weiss, L.M. (1992). Epstein-Barr virus-associated gastric adenocarcinoma. Am. J. Pathol. 140, 769-74.

48. Shin, W.S.; Kang, M.W.; Kang, J.H.; Choi, M.K.; Ahn, B.M.; Kim, J.K.; Sun, H.S.; Min, K.W. (1996). Epstein-Barr virus-associated gastric adenocarcinomas among Koreans. Am. J. Clin. Pathol. 105(2), 174-81.

49. Shousha, S.; Luqmani, Y.A. (1994). Epstein-Barr virus in gastric carcinoma and adjacent normal gastric and duodenal mucosa. J. Clin. Pathol. 47(8), 695-8.

50. Sugawara, Y.; Mizugaki, Y.; Uchida, T.; Torii, T.; Imai, S.; Makuuchi, M.; Takada, K. (1999). Detection of Epstein-Barr virus (EBV) in hepatocellular carcinoma tissue: a novel EBV latency characterized by the absence of EBV-encoded small RNA expression. Virology. 256(2), 196-202.

51. Takada, K. (2000). Epstein-Barr virus and gastric carcinoma. Mol. Pathol. 53, 255-61.

52. Takano, Y.; Kato, Y.; Saegusa, M.; Mori, S.; Shiota, M.; Masuda, M.; Mikami, T.; Okayasu, I. (1999). The role of the Epstein-Barr virus in the oncogenesis of $\mathrm{EBV}(+)$ gastric carcinomas. Virchows Arch. 434(1), 1722. 
53. Telenti, A.; Marshall, W.F.; Smith, T.F. (1990). Detection of Epstein-Barr virus by polymerase chain reaction. J. Clin. Microbiol. 28(10), 2187-90.

54. Tokunaga, M.; Uemura, Y.; Tokudome, T.; Ishidate, T.; Masuda, H.; Okazaki, E.; Kaneko, K.; Naoe, S.; Ito, M.; Okamura, A. (1993). EpsteinBarr virus related gastric cancer in Japan: a molecular pathoepidemiological study. Acta Pathol. Jpn. 43(10), 574-81.

55. Trimeche, M.; Ksiâa, F.; Ziadi, S.; Mestiri, S.; Hachana, M.; Gacem, R. B.; Sriha, B.; Korbi, S. (2009). Prevalence and characteristics of EpsteinBarr vírus-associated gastric carcinomas in Tunisia. European Journal of Gastroenterology \& Hepatology. 21, 1001-07.

56. Truong, C. D.; Feng, W.; Li, W.; Khoury, T.; Li, Q.; Alrawi, S.; Yu, Y.; Xie, K.; Yao, J.; Tan, D. (2009). Characteristics of Epstein-Barr virusassociated gastric cancer: A study of 235 cases at a comprehensive cancer center in USA. Journal of Experimental \& Clinical Cancer Research. 28(14), 1-9.

57. Wang, Y.; Luo, B.; Zhao, P.; Huang, B.H. (2004). Expression of Epstein-
Barr virus genes in EBV-associated gastric carcinoma. Ai. Zheng. 23(7), $782-7$.

58. Yanai, H.; Takada, K.; Shimizu, N.; Mizugaki, Y.; Tada, M.; Okita, K. (1997). Epstein-Barr virus infection in non-carcinomatous gastric epithelium. J. Pathol. 183(3), 293-8.

59. Yoshiwara, E.; Koriyama, C.; Akiba, S.; Itoh, T.; Minakami, Y.; Chirinos, J.L.; Watanabe, J.; Takano, J.; Miyagui, J.; Hidalgo, H.; Chacon, P.; Linares, V.; Eizuru, Y. (2005) Epstein-Barr virus-associated gastric carcinoma in Lima, Peru. J. Exp. Clin. Cancer Res. 24(1), 49-54.

60. Yuen, S.T.; Chung, L.P.; Leung, S.Y.; Luk, I.S.; Chan, S.Y.; Ho, J. (1994). In situ detection of Epstein-Barr virus in gastric and colorectal adenocarcinomas. Am. J. Surg. Pathol. 18(11), 1158-63.

61. Zur Hausen, A.; van Rees, B.P.; van Beek, J.; Craanen, M.E.; Bloemena, E.; Offerhaus, G.J.; Meijer, C.J.; van den Brule, A.J. (2004). Epstein-Barr virus in gastric carcinomas and gastric stump carcinomas: a late event in gastric carcinogenesis. J. Clin. Pathol. 57(5), 487-91. 